\title{
Self-assessed attitudes of adolescents towards learning
}

\author{
Self-assessed attitudes of adolescents towards learning \\ Abstract
}

The article presents the results of a pedagogical study, recently conducted on a group of over 8 thousand adolescents on the self-assessment of attitudes towards learning. As technologies have shifted many points of focus in addressing learning as an essential aspect of the educational process, the author intended to analyze the representations of adolescents from the knowledge and information century, administering an online questionnaire consisting of different types of questions. The results revealed diverse and mature perceptions, problems of teacher-student, student-student relations, of the institutional process of organization / culture of learning, but also of its results, as perceived by the main actors of the educational act.

\section{Keywords}

attitudes, representations, perceptions, self-assessment, adolescents, learning, educational process

\section{Introduction}

The more and more intense changes of the representations of students, but also of young people, adults, in general, on the attitude towards learning, as a process and as a result, determined us to research, in a practical way, the problem in question. There is nothing new about the fact that the technology of the $21^{\text {st }}$ century has substantially changed not only the perceptions of why and how we should learn, but also the everyday behaviors that motivate and generate the act of learning as such. Our online study finds that most middle and high school students (ages 12-18) have an adequate perception of learning as work and as a guarantee of success in their future careers, but the academic results recorded, including the ones at the end of middle school and high school do not confirm this. Studies conducted with 
the participation of teachers and parents do not confirm this either. This gradual decrease alarms the educational actors at various levels and generates the need to re-think and re-dimension the educational process, in general. The research on the issue of learning on a large group of adolescents was motivated by the fact that, from a psychological point of view, childhood and adolescence, as periods of expansion in the field of learning ${ }^{1}$, determine the intellectual and moral path of the personality, despite the confrontations with multiple problems and challenges, from the "identity crisis to the property crisis", and also the delicate periods of development coincide with the optimal periods for learning ${ }^{3}$.

\section{Conceptual aspects}

In the last decade, the global educational community has benefited from diverse psychological, social, economic, pedagogical studies on learning, in different countries of the world, while experts from different generations and with diverse academic and sociocultural experience have been concerned with the learning approach. We will quote a more than relevant and comprehensive excerpt from the study entitled "Natural born learners", the reading of which motivated us, among other things, to conduct the following research in the Republic of Moldova:

Learning is the soul of our species. From the first steps to the last words, we are what we learn. Education predicts how much we will earn, how satisfied we will be and even how long we will live. But despite its obvious importance, learning has lost touch with human progress. We live in an information age and work in an economy of knowledge, but our schools are relics of the industrial age ${ }^{4}$.

We deduce from this context the idea that certain elements of the complex education system do not work and they cannot satisfy the sociocultural mission entrusted to the school, as well as the expectations, the needs of the individual and the ones of the family, of the community to which one belongs.

Despite the fact that in the current National curriculum, focused on competencies, which are defined as "an integrated system of knowledge, skills, attitudes and values acquired / formed and developed through learning (the emphasis belongs to us), whose mobilization allows the identification and solving of different

\footnotetext{
${ }^{1}$ G. Pânișoară (coord.), Psihologia învățării. Cum învață copiii și adulți / Learning psychology: How children and adults learn, Iași 2019, p. 21.

${ }^{2}$ Vl. Pâslaru, Introducere în teoria educației literar-artistice / Introduction to the theory of literary-artistic education, București 2013, p. 78.

3 Apud G. Pânișoară (coord.), op.cit., p. 119.

${ }^{4}$ Al. Beard, Născuți pentru a învăța / Natural born learners, Bucureşti 2019, p. 7.
} 
problems in various contexts, life situations"', pedagogical practice, recent studies show that the formation of key competencies remains a more difficult goal to achieve, for most students, as beneficiaries of the educational process.

Re-visiting on this occasion reference sources from the Romanian pedagogical literature, we updated an axiom from S. Cristea's Dictionary of pedagogical terms, reiterated at the university courses for future pedagogical students: "Learning, as a fundamental human activity, has its own purpose, committed at the level of adaptive finality transmitted to its subordinate actions (writing, reading, etc.), designed and realized by virtue of specific motivations"6. Therefore, adaptation as a goal of learning, including the transition from one era to another, in our case, from the industrial age to that of information / knowledge, is influenced by specific factors, and among the many theories that have studied it, the constructivist one, imposes itself for various philosophical and pragmatic reasons. Among the internal factors that influence it at the level of human personality, in our study we will insist on the attitudinal, affective, motivational and of character, but also on the external ones, starting with the organization of school life, continuing with the teaching-learning-evaluating methodology and ending with the sociocultural environments in which the student works. Regarding the learning environment, we offer another quote for the reflections of those interested, from a previously quoted source:

We need gigantic changes. Schools should be like palaces. The competition for the best teachers should be fierce. These people should earn a 6-digit income. Schools should be incredibly expensive for the government and absolutely free for citizens, just like national defense. (...) Let's be ready to start a revolution in the learning field ${ }^{7}$.

Researching the phenomenon of learning in the complex and dynamic context of postmodernism, L. Ciolan argues that

learning is integrated in all aspects of life and in turn, when it occurs, it integrates, all the essential aspects of the human being. Learning means change: its processes are generated by the need to change of the individual, organizational or large social entities. Since complexity and change are two essential characteristics of contemporary society, here is a first argument for the concept of a learning society ${ }^{8}$.

${ }^{5}$ Cadrul de referință al Curriculumului Național / Reference framework of the National Curriculum, Chișinău 2017, p. 19.

${ }^{6}$ S. Cristea, Dicţionar de termeni pedagogici / Dictionary of pedagogical terms, București 1998, p. 244.

7 Al. Beard, op.cit., p. 408.

${ }^{8}$ L. Ciolan, Învățarea integrată. Fundamente pentru un curriculum transdisciplinar / Integrated learning: Fundamentals for a transdisciplinary curriculum, Iași 2008, p. 77. 
In this context, the educational sciences have expanded, imposing the active and interactive pedagogy, which, according to M.-D. Bocos,

makes the student responsible, one who assumes the learning, favors the construction of the meaning of new knowledge and autonomy; it is a pedagogy of work and effort, of intellectual, social, verbal and affective exchanges and of conciliation, conviction and enthusiasm, in which social interactions and cognitive processes are seen as complementary ways of achieving scientific knowledge?

The individual, who learns actively and interactively, is his own initiator and organizer of learning experiences, able to constantly reorganize and restructure his own acquisitions, in a systemic vision.

Through active learning, we aim for students to gradually become able to develop individualized personalized learning projects, take responsibility for them, become aware of them, apply them, evaluate and improve them, monitor, manage and self-regulate their learning, acquiring, progressively, autonomy in learning and training ${ }^{10}$.

As the representations about learning have a social character, being dynamic and flexible, throughout life, depending on different contexts, it is important for educators to understand that, from a structural point of view, they include the representation of the self, the task, others and the context. All these, in the development process, including the school years, "interact and determine the significance of the situation for the subject, inducing the behaviors, the cognitive approaches and the type of inter-individual or intergroup relations"11. The impact of education, especially in the critical period of adolescence, has a defining and significant role, that is why we insist on significant didactic approaches for them, with practical and impactful purposes. The mission of the school in this sense is crucial, especially through the contribution to the achievement of the finalities, stipulated in art. 11 of the Education Code - (f) - the competence of learning to learn ${ }^{12}$. Being in the structural epicenter of the education process - teaching-learning-evaluating, the other two sides have no meaning and no achievement without it. Also, in European documents, this competence is characterized as

the ability to persevere in learning, to organize one's own learning, including through the efficient management of time and information, both individually and in groups. This com-

${ }^{9}$ M.-D. Bocoș, Instruirea interactivă. Repere axiologice și metodologice / Interactive teaching: Axiological and methodological landmarks, Iași 2013, p. 50.

${ }^{10}$ Ibidem, p. 86.

${ }_{11}$ M. Boza, Atitudinile sociale și schimbarea / Social attitudes and the change, Iași 2010, p. 77.

${ }_{12}$ Codul Educației al Republicii Moldova / Education Code of the Republic of Moldova, Chișinău 2014. 
petence includes awareness of the learning process and needs, identification of available opportunities and the ability to overcome obstacles in order to successfully learn. This competence means accumulating, processing and assimilating new knowledge and skills, as well as seeking and using counseling and guidance. Learning to learn involves learners starting from previous knowledge and life experiences, so that they can use and apply knowledge and skills in a variety of contexts: at home, at work, in education and training. Motivation and confidence are crucial for this competence ${ }^{13}$.

A consistent teaching support "A key competence - Learning to learn", was developed 10 years ago by a group of expert-trainers from EC PRO DIDACTICA, offering a diverse set of teaching interactive strategies that can be used in various school subjects, but also in non-formal education ${ }^{14}$.

From an epistemological point of view, "we define attitudes as significant relations of the man-individual towards things and beings and towards his own being, his own intimate universe"15. According to the researcher T. Callo, for multidimensional and sustainable attitude education in childhood and adolescent's years, for young people and adults, we need a "practical pedagogy, and its modification is a complex field, there are many strategies, theories and models that try to explain this phenomenon"16.

The crucial role of parents and teachers in building learning skills and feeding the "taste" for intellectual work is recognized by specialists in a large number of fields concerned with the study of learning. These key educational actors are going to transform day by day "learning into an active, personalized, creative process and into a creator of existential meanings" ${ }^{17}$. In the same context, the psychologist recommends tireless support and encouragement of learning, going even further by infecting others with this pleasure, meaning that "children who learn about their motivation and that of others will be able to use the power of learning to grow into successful adults"18.

From the point of view of educational policies, learning as a basic process attributed to the school, is adequately stressed, anchored in current realities. The frame of reference of the National Curriculum of the Republic of Moldova,

${ }^{13}$ Education Council, Recommendation of the European Parliament and the Council of 18 December 2006 on key competences for lifelong learning, "Official Journal of the European Union", Brussels 30.12.2006.

${ }^{14}$ V. Goraș-Postică (coord.), O competență cheie: a învăța să înveți / A key skill: learning to learn, Chișinău 2010.

${ }_{15}$ Vl. Paslaru, op.cit., p. 30.

${ }_{16}$ T. Callo, Pedagogia practică a atitudinilor / Practical pedagogy of attitudes, Chișinău 2014, p. 79.

${ }^{17}$ Fl. Golu, Forme și stiluri de învățare, [in:] G. Pânișoară (coord.), op. cit., p. 178.

${ }^{18}$ Ibidem, p. 195. 
regarding the chapter Generic Attributes to School Graduates, recommends the education of "people open to lifelong learning", who "demonstrate a positive attitude and pleasure, interest and motivation for learning; analysis and reflection on one's own learning and involvement for learning optimization; establishing one's own goals in learning; openness to new ways of thinking and new ideas; interest and involvement in formal, non-formal and informal learning activities; effort for fast and efficient learning"19. Of course, in the Application field things are not as good as they are conceived in the regulatory documents, and the visible impact in society continues to be far from that projected in the policy acts, but also from the expectations of most citizens who have the courage to stay home and to contribute to the edification of society, but also of those who leave disappointed towards better realms, where the effects of learning are felt and probably seen as better.

\section{Finding investigation: methodology and results}

In order to identify the current representations of middle and high school students in the Republic of Moldova, on learning, as a basic school responsibility, during February 2021, we distributed, through teachers and school psychologists, a questionnaire compiled by us, deliberately containing different types of items and proposed for online completion / in Google form. Next, we will, analytically, go through the answers obtained on a batch of 8090 respondents (the benefit of technology!), aged between 12 and 17 years. Although they were relatively sent equally to teachers in both villages and cities, more students from urban areas responded, the proportion of village-city being 79.3 to 20.7 (a representative of the ratio of students in the country to the given size), of which the number of girls and boys is relatively equal. The reason why students go to school every day (the starting question) was to be chosen from a few basic options, as a priority, and the answers obtained were put on the scale in Fig. 1:

The fact that students know very well why they come to school is no surprise, it is a natural thing, but the $9.3 \%$ of respondents, who gave priority to meetings with friends or simply that "That's the way it should be" arouse concern, behind which can be hidden misunderstandings and alarming confusions, harmful to the personality development of adolescents.

${ }_{19}$ Cadrul de referință al Curriculumului Național / Reference framework of the National Curriculum, op. cit., p. 34. 


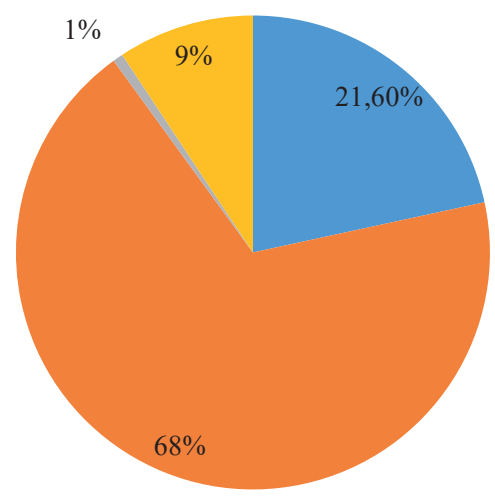

That's the way it should be

- To work, learning

To have fun

$\square$ To see my friends, colleagues

Fig. 1. Why do you come to school every day?

The next question assessed the desire to learn, the pleasure itself, caused by intellectual work and was characterized below on the group surveyed by the percentage shares in Fig. 2. Almost a third of the respondents (19.7\% - a little, 10.6\% I don't know, 2.3\% - not at all) do not agree with the main type of work promoted at school, this becoming a chore for them. Such a situation is manifested in every class / school, when about a third of children perceive school as something parallel to their own interests and concerns. Obviously, these things must be "compensated" / filled with other types of tasks in each lesson, by teachers, so as not to completely lose sight of these children.

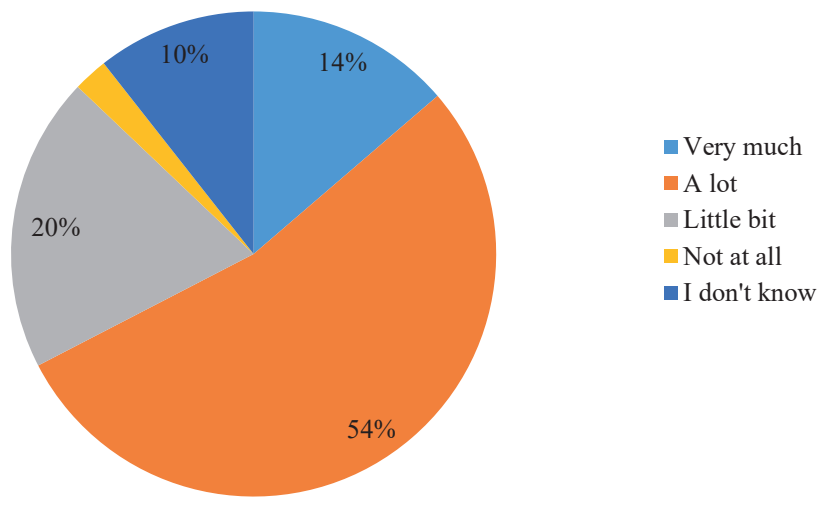

Fig. 2. How much do you like to learn, to work intellectually?

The extent to which good learning outcomes are thought to help them succeed in life, have a good job, was asked to be obtained by circling the answers and, respectively, students opted for the following quantitative results, represented 
in fig. 3-4. Among the options given are those with the reason "for self-development" and "for a successful career", which are welcome and gratifying, but at the same time, the fact that these two are followed by "I do not know exactly", chosen as a priority by half of the respondents, does not leave us any time and space for relaxation / satisfaction.
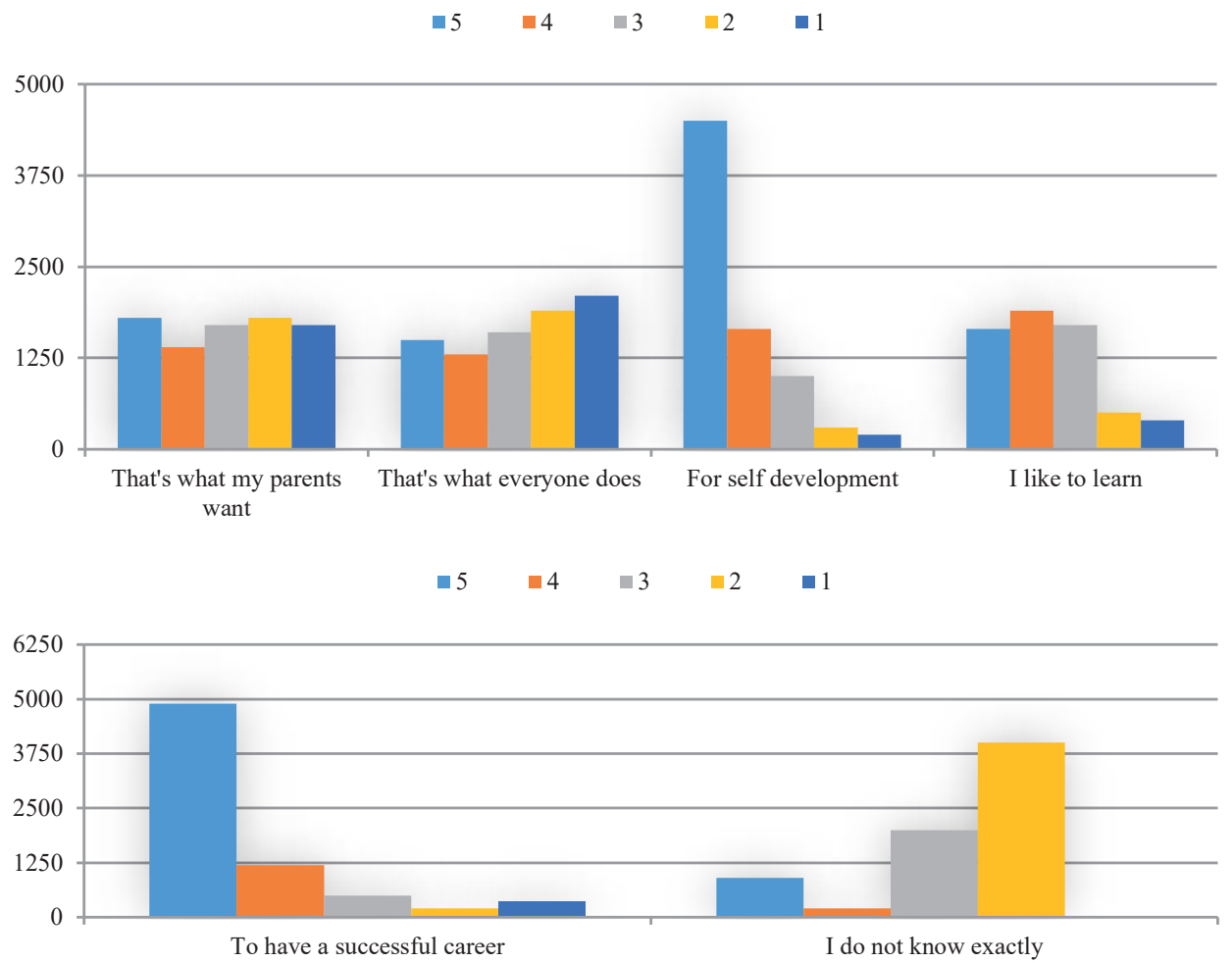

Fig. 3-4. What are the reasons you need to learn well in school?

Subsequently, about one third (30.5\%) of the respondents said that school learning outcomes can be used to ensure success in life to a very large extent, and $28.3 \%$ - to a large extent, the total being $58.8 \%$, followed by $28.95 \%$ - in an average measure and the other 3 options of undecided participants (a small measure, not at all and I do not know), accumulating $12.25 \%$. However, adding the last two percentages, we find that $41.2 \%$ of students are reluctant to speak out in favor of the contribution of learning to the success in life, which is quite a lot, from a statistical point of view, easily approaching almost half the lot. In this sense, increasing the functionality of curricular content and learning tasks remains as the order of the day in every classroom. These answers were also verified by the question: To 
what extent do you agree with the following Latin maxim: We learn for life, not for school / Non scholae, sed vitae discimus (we repeat this in our college years). And here answered $23.9 \%$ of students: "No" - (11.3\%) and "I don't know" - (12.6\%) (fig. 5).

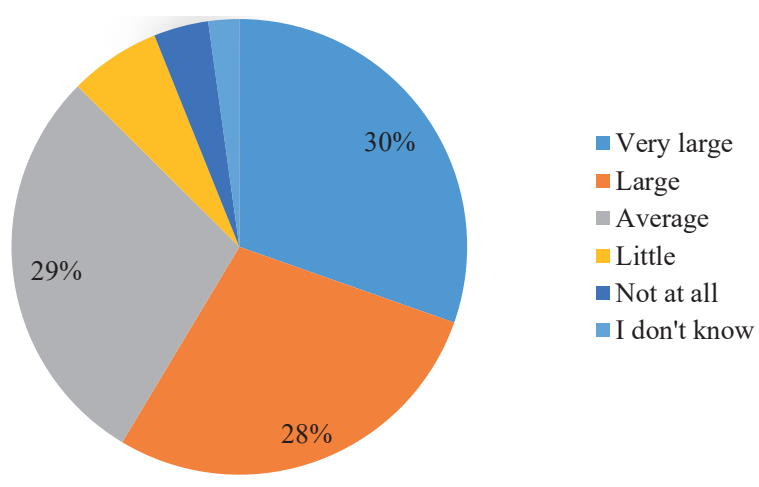

Fig. 5. To what extent do you think that good school results can help you succeed in life, having a good job

The estimation of the learning-work-effort correlation was evaluated by expressing agreement/disagreement with an ordinary statement, repeated by adults of different generations. In order to have good learning outcomes, you have to work hard every day.

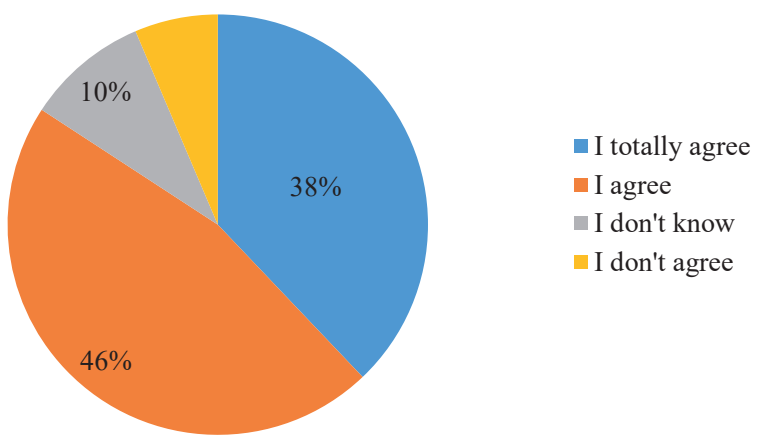

Fig. 6. To what extent do you agree with the statement: "In order to have good learning outcomes, you have to work hard every day"

We emphasize as problematic, in the context represented by the answers above, the $15.8 \%$, well over a thousand children who do not see a correlation between learning and work/effort. Meaning that, "a more productive and, in fact, scientifi- 
cally correct theory is the one that considers effort as a way to improve intellectual abilities. If we work, we can enrich our knowledge and improve our skills. It is up to us to succeed in what we want to do, and to achieve this we must put a lot of effort and use our personal resources wisely" ${ }^{20}$ - a goal that should become an axiomatic truth in the consciousness of our students.

The role of the teacher in supporting and facilitating the learning act - "Teachers in school help me understand what I have learned, in order to have good results and to feel good at school" is perceived differently, obviously, over a quarter of adolescents (26.6\%) do not feel this way. This situation must be researched and addressed as a problem of the education system as a whole.

The existence and promotion of the culture of learning and intellectual work, as an element of the organizational culture, in the opinion of students, was estimated as follows: "I totally agree" - 31.8\%, "I agree" - 56\% and "I do not feel this" $-12.1 \%$. It probably sounds too categorical or our expectations from teenagers were too high, but given that inside the knowledge society, the culture of learning is more than necessary and present, undoubtedly, students should decide, to contribute to its edification, appropriating themselves some inherent values circumscribed by it ${ }^{21}$.

The last three questions in the questionnaire contained open items, the first being to complete the statement - In order to learn better at school and at home, I need..., intending to collect / update the needs perceived by students for successful learning. In this context, more than a third of respondents said that they need: attention, peace, motivation, desire to learn, patience, effort, work, endeavor, support, understanding, clear explanations from teachers, time, but at the same time, almost a quarter of them opted for I don't know. Also, among other needs, appearing as a priority were the: (new) books / textbooks, technology, Internet, school supplies, classroom presence, etc. Obviously, the students pointed out some gaps in the existing organizational culture, which are felt in the institutionalized educational system, meaning that, every second adolescent, in addition to the requirements imposed by themselves and recognizing them as important from their perspective, also recognized peace and understanding, and explanations from the teacher as a priority. The needs related to peace were highlighted in the conditions of distance learning, when students with more advanced intellectual abilities acknowledged

${ }^{20}$ D. Goia, Ghid al activităților pentru a învăța să înveți în școli / Activites guide for learning to learn in schools, Bucureşti 2019, http://euroguidance.ise.ro/wp-content/uploads/2019/01/ ghid_a_ invata sa_inveti.pdf [access: 10.02.2021].

${ }^{21}$ Cf. V. Goraș-Postică, Învăţarea ca dimensiune de existenţă a unei organizaţii (studiu aplicativ) / Learning as a dimension of an organization's existence (Applied study), "Didactiaca Pro..." 2002, no. 6 (16), pp. 8-16. 
that: At home no one bothers me to concentrate and I can learn better. Here are some conclusive answers to the previous question:

- Repeated explanations, it may sound strange, but I'm afraid to tell the teacher that "I don't understand the topic", not that he would do something to me, but when I want to do that, I'm automatically thinking that I'm wasting time, for the teacher to just explain things to me, instead of continuing the lesson normally... I'm behind with the homework that I don't understand and, because of this fear, I can't let myself understand it clearly...".

- In order to learn better in school, I need understanding teachers to support me and help me when I don't understand or fail, but not to criticize me in front of my classmates or turn the whole class against me, hoping that I will learn better or change my behavior (the hope is non sense, they have no idea).

- In order to feel comfortable and happy at school, teachers should not allow other classmates to mock me or BULLY ME, THEY SHOULD DO SOMETHING ABOUT IT, but to them, in fact, it is not important and they don't care about the feelings and emotions of the student. At home I have everything I need to take care of school, but it is in vain as our "much-loved" ministry does nothing with these textbooks that are as heavy as hell and that contain such stupid assignments that make me shiver.

The next, same type question, confirmed the answers from the previous one For our teaching at school to become a pleasure, to make sense, I recommend to my colleagues... - and collected a very wide range of relevant qualitative answers, which suggest some substantial changes expected of students with reference to the education system and process. Most of the time (in more than a quarter of answers), in this context, the respondents repeat the advice offered to colleagues: to learn, to pay more attention, to listen to the teachers, to be more respectful with colleagues and teachers, to put phones aside during the lessons, to be more serious, more responsible, politer, not to be lazy, etc. It would seem that students know these things since primary school, but...

In order the students learn very well, to understand what is taught in class, I recommend to my teachers.... - was the last question, to which there were mature and conscious answers regarding the factors of success in learning, including critical attitudes:

a) the teaching methods: to explain clearly (just over a third of the answers); to answer students' questions; to provide arguments, examples; to teach in an interesting way; to speak slower and clearer, etc.;

b) in the curriculum: We are waiting for the renewal of the educational system. We are learning according to the same system our parents' used to learn. Most things in science are outdated, especially the current model of computer science teaching. I'm not talking about a total reconstruction of the system, 
following the model of other countries (USA / Japan / Norway, etc.), (which would be desirable), but at least about some essential changes in the curriculum. It needs to be revised and refined. Bring us news, innovations in the classroom;

c) the attitude towards students: not to get angry; to be calm; not to shout / yell / not to raise their tone (approx. a quarter of answers); to retire; not to verbally assault us; to be more tolerant, more understanding, to understand that day students have other requirements and values, etc.; Teachers should explain homework slowly and clearly, but not as if they are going to miss their train, because these are new topics for the students and we can neither manage to write from the board, nor listen and understand, and they should not laugh or amuse themselves over how easy it is for the student to learn or how he perceives the world. Teachers should respect the student's opinions, and not indoctrinate him with their beliefs from Lenin's time. To have an equal attitude towards all students, to treat them all the same way... "Don't threaten us with the final exams, don't kill us with so many repetitions for the final exams, even if we still don't understand".

It is not a novelty either that in terms of insuring qualified teachers, the Moldovan society has a major delay, on the one hand, teachers are considered as being wronged, on the other hand, students and parents have quite high expectations from them. "A society that does not love its teachers, does not love its children either. Teaching can be the ultimate craft" ${ }^{22}$, in ensuring the success of learning, says A. Beard, and pedagogy faculties should train future teachers inside schools, not between the theoretical walls of universities, says the same researcher. The vast majority of the answers obtained are confirmed by other studies in the field, for example: "In three out of five educational institutions, the teaching-learningevaluation process is affected by the lack of teachers and educational materials" 23 . It is obvious that the education system is trying to solve all the problems, but there are still ingrained shortcomings, which still persist in the education system. We mention the differences between the rates of promotion of the national exams for the language of instruction and the competencies of the students in passing the PISA tests in the Republic of Moldova. Even if some of these differences can be explained by different approaches, the fact that more than half of the students do not reach the minimum level of skills raises obvious signs of concern ${ }^{24}$.

22 Al. Beard, op. cit., p. 418.

23 V. Crișciuc, Rezultatele evaluării PISA 2018: dimensiuni, conexiuni şi așteptări privind evaluările internaționale și naționale ale elevilor / Results of the PISA 2018 assessment: dimensions, connections and expectations regarding international and national student assessments, https://www. soros.md/files/publications /documents/ Crisciuc_compressed.pdf [access: 18.02.2021].

${ }^{24}$ Ibidem, p. 32. 


\section{Conclusions and perspectives}

The conducted study was complex and provided us with relevant quantitative and qualitative results, worthy of consideration in the operation of strategic and operational steps to restructure education at the system and process level. Among the limits of our study, obviously, one is a priority related to attitude measurement, "as a controversial issue in psychology and sociology", when "the direct path self-assessment through introspection (...) is filtered by the subjective" 25 . Despite this, however, the need to develop the character and sustainable learning skills in students, is required, especially through the development of systematic actions of lifelong learning, critical thinking, stimulating creativity and innovation, through individual activities, but also through cooperation (the I Generation gives way to the Us Generation) ${ }^{26}$, rational and wise use of technology, etc. Ultimately, the purpose of building the future through learning becomes a fundamental action imperative: "Instead of preparing them for a future they cannot predict, our children can create it (...) Learning is not the solitary act of developing your abilities, but an effort to carry our society forward"27, and for this we need collective transformational leadership, will and social solidarity in implementing essential social and cultural changes.

\section{Bibliography}

Beard Al., Născuți pentru a învăța / Natural born learners, București 2019.

Bocoș M.-D., Instruirea interactivă. Repere axiologice și metodologice / Interactive teaching: Axiological and methodological landmarks, Iași 2013.

Boza M., Atitudinile sociale și schimbarea / Social attitudes and the change, Iași 2010.

Cadrul de referință al Curriculumului Național / Reference framework of the National Curriculum, Chișinău 2017.

Callo T., Pedagogia practică a atitudinilor / Practical pedagogy of attitudes, Chișinău 2014.

Ciolan L., Învățarea integrată. Fundamente pentru un curriculum transdisciplinar / Integrated learning: Fundamentals for a transdisciplinary curriculum, Iași 2008.

Codul Educației al Republicii Moldova / Education Code of the Republic of Moldova, Chișinău 2014.

Cristea S., Dicționar de termeni pedagogici / Dictionary of pedagogical terms, Bucureşti 1998.

Crișciuc V., Rezultatele evaluării PISA 2018: dimensiuni, conexiuni și așteptări privind evaluările internaționale și naționale ale elevilor / Results of the PISA 2018 assessment: dimensions, connections and expectations regarding international and national student assessments, https://www. soros.md/files/publications /documents/Crisciuc_compressed.pdf [access: 18.02.2021].

\footnotetext{
25 M. Boza, op.cit., p. 37.

26 Al. Beard, op.cit., p. 417.

27 Ibidem, p. 421.
} 
Education Council, Recommendation of the European Parliament and the Council of 18 December 2006 on key competences for lifelong learning, "Official Journal of the European Union", Brussels 30.12.2006.

Goia D., Ghid al activităților pentru a învăța să înveți în școli / Activites guide for learning to learn in schools, Bucureşti 2019, http://euroguidance.ise.ro/wp-content/uploads/2019/01/ ghid_a_invata sa_inveti.pdf [access: 10.02.2021].

Golu Fl., Forme și stiluri de învățare, [in:] Pânişoară G. (coord.), Psihologia învățării. Cum învață copiii și adulți / Learning psychology: How children and adults learn, Iași 2019.

Golu Fl., Manual de psihologia dezvoltării. O abordare psihodinamică / Psychology textbook: A psychodynamic approach, Iași 2015.

Goraș-Postică V. (coord.), O competență cheie: a învăța să înveți / A key skill: learning to learn, Chișinău 2010.

Goraș-Postică V. Învăţarea ca dimensiune de existenţă a unei organizaţii (studiu aplicativ) / Learning as a dimension of an organization's existence (Applied study), "Didactiaca Pro..." 2002, no. 6 (16), pp. 8-16.

Pânișoară G. (coord.), Psihologia învățării. Cum învață copiii și adulți / Learning psychology. How children and adults learn, Iași 2019.

Pâslaru Vl., Introducere în teoria educației literar-artistice / Introduction to the theory of literary-artistic education, Bucureşti 2013. 